\title{
Diversity of Ophioniformes wasps (Hymenoptera: Ichneumonidae) in a Central-West Brazilian Savanna area
}

\author{
Alvaro Doria dos Santos ${ }^{1,3}$; Helena Carolina Onody ${ }^{2,4}$ \& Carlos Roberto Ferreira Brandão ${ }^{1,5}$
}

\author{
1 Universidade de São Paulo (USP), Museu de Zoologia (MZUSP). São Paulo, SP, Brasil. \\ ${ }^{2}$ Universidade Estadual do Piauí (UESPI). Corrente, PI, Brasil. \\ ${ }^{3}$ ORCID: http://orcid.org/0000-0002-7997-4195. E-mail: alvarods3@gmail.com \\ ${ }^{4}$ ORCID: http://orcid.org/0000-0003-3570-8183. E-mail: helenaonody@gmail.com \\ 5 ORCID: http://orcid.org/0000-0002-4689-5845. E-mail: crfbrand@usp.br
}

\begin{abstract}
This study aimed to assess the diversity, abundance and seasonal dynamics of Ophioniformes wasps collected throughout a year, as recorded in Malaise traps set at the Reserva Ecológica da Universidade Estadual do Mato Grosso do Sul, a Brazilian Savanna area in Aquidauana city, MS. A total of 621 specimens of Ophioniformes belonging to 11 subfamilies, 30 genera and 106 species were sampled. Despite the impressive number of species found, in a pattern of a few relatively abundant species and many rare ones, our data estimate even higher richness, probably between 125 to 165 species in the studied area. The genera Diadegma, Nonnus, Diradops, Meniscomorpha, Syzeuctus, Ophiopterus and Thyreodon are recorded for the first time in Mato Grosso do Sul State. Among the climatic variables evaluated, mean temperature and relative humidity were positively and significantly correlated with richness and abundance. Our data highlights the huge unknown species richness of these parasitoids in Brazil and the need of taxonomic studies efforts in the future.
\end{abstract}

Keywords. Darwin Wasps; Faunal survey; Ichneumonid; Malaise trap, Brazilian savanna.

\section{INTRODUCTION}

The Ichneumonidae (Hymenoptera), known as Darwin wasps, is a comparatively large clade of cosmopolitan parasitoid wasps (Quicke, 2015; Klopfstein et al., 2019). The latest catalogue indicates 25.285 valid nominal species recorded up to 2015 making it the richest Hymenoptera family (Yu et al., 2016). Despite this rich profusion of known species, there are still many taxa to be described, especially in poorly studied places mostly in the Southern Hemisphere (Sääksjärvi et al., 2004; Quicke, 2012; Veijalainen et al., 2014; Gómez et al., 2018; Meierotto et al., 2019). Within ichneumonid wasps, the clade Ophioniformes (Wahl, 1991) has been recovered as monophyletic by recent phylogenetic studies (Quicke et al., 2000, 2009; Bennett et al., 2019) and includes the following 18 subfamilies: Anomaloninae, Banchinae, Campopleginae, Cremastinae, Ctenopelmatinae, Hybrizontinae, Lycorininae, Mesochorinae, Metopiinae, Oxytorinae, Neorhacodinae, Nesomesochorinae, Ophioninae, Sisyrostolinae, Stilbopinae, Tatogastrinae, Tersilochinae and Tryphoninae.

Members of this group for which the host biology is known are all koionbionts and all except
Tryphoninae (the sister group to all other subfamilies) are endoparasitoids (Bennett et al., 2019). They parasitize larvae and pupae of a broad array of holometabolous insect orders, most commonly Lepidoptera, but also Hymenoptera, Coleoptera (Quicke, 2015 and references therein) and less commonly Raphidioptera (Spöck, 2002).

In Brazil, there are 368 described species of recorded Ophioniformes (Yu et al., 2016; Fernandes et al., 2020a) from almost all 18 subfamilies, except for Hybrizontinae, Sisyrostolinae, Stilbopinae and Tatogastrinae. Surveys of ichneumonid fauna including this clade, with identification of at least subfamily level, were conducted predominantly in the South (Kumagai \& Graf, 2000; Kumagai \& Graf, 2002) and Southeastern regions of Brazil (Guerra \& Penteado-Dias, 2002; Kumagai, 2002; Sandonato et al., 2010; Comério et al., 2012; Tanque et al., 2010). Over the last years, Darwin wasps faunistic surveys have been conducted in the Brazilian Central-West and Northeast regions (Aranda \& Graciolli, 2015; Fernandes et al., 2019, 2020b).

The Brazilian Savanna (known as Cerrado) is recognized as a crucial area for conservation due to its relatively high diversity and presence of 
endemic species (Mittermeier et al., 2011). It occupies $1,983,017 \mathrm{~km}^{2}$ of the Brazilian territory, extending over thirteen federation states, including most of Mato Grosso do Sul state (MS) (IBGE, 2019). Despite its significance for species conservation, deforestation rates in this biome were 2.5 times higher than in the Amazon rainforest between the years 2002 and 2011 (Strassburg et al., 2017). Fast increase of agribusiness and infrastructure development combined with badly enforced environmental laws are leading to a major biodiversity collapse of this biome (Colli et al., 2020).

Improvement on the knowledge of Ichneumonidae fauna is helpful to enable taxonomic studies and reviews (Klopfstein et al., 2019), to use this information as a tool for environmental assessment (Mazón, 2016), and even to discover possible biological control agents (Townes, 1971; Gupta, 1991; Neto et al., 2004). So, this study aimed to assess the diversity, abundance and seasonal dynamics of Ophioniformes wasps collected throughout a year using Malaise traps in the Reserva Ecológica da Universidade Estadual do Mato Grosso do Sul, from a Brazilian Savanna area.

\section{MATERIAL AND METHODS}

\section{Study area}

All Ichneumonid specimens here recorded were gathered by the project "Diptera from Mato Grosso, Mato Grosso do Sul and Rondônia states: diversity, systematics and distributional limits", which employed mass collecting using Malaise traps, from September/2011 to August/2012, completing a full year of continuously (day and night, approximately 26,300 hours) operated three Malaise traps. Each of these traps had $3.4 \mathrm{~m}^{2}$ of catch area and contained flasks filled with ethanol $70 \%$ which were emptied every fortnight periods. The Malaise traps were placed at the Reserva Ecológica da Universidade Estadual do Mato Grosso do Sul (Aquidauana city, MS; Fig. 1A-C), each one in a collecting sites, with the following characteristics: Seasonal Deciduous Forest with closed vegetation $\left(20^{\circ} 26^{\prime} 03.7^{\prime \prime} \mathrm{S}\right.$, $\left.55^{\circ} 39^{\prime} 20.8^{\prime \prime} \mathrm{W}\right)$; Seasonal Deciduous Forest with open vegetation $\left(20^{\circ} 25^{\prime} 59.0^{\prime \prime} \mathrm{S}, 55^{\circ} 39^{\prime} 20.8^{\prime \prime} \mathrm{W}\right)$; Riparian Forest $\left(20^{\circ} 26^{\prime} 07.2^{\prime \prime} \mathrm{S}, 55^{\circ} 39^{\prime} 32.8^{\prime \prime} \mathrm{W}\right)$. The study area climate is classified according to the Köppen criteria as tropical Savanna climate (Aw): with mean monthly temperatures above $18^{\circ} \mathrm{C}$, and a relatively dry winter, with less than $60 \mathrm{~mm}$ of precipitation in the driest month (Alvares et al., 2013).

\section{Specimens treatment and data analysis}

Specimens were sorted, dry mounted, labelled and deposited at the Museu de Zoologia da Universidade de São Paulo (MZSP) Hymenoptera collection. Individuals were identified in subfamilies sensu Bennett et al. (2019) and those belonging to the Ophioniformes were sepa- rated into genera. Further identification was restricted to morphologically similar individuals based on characters in Gauld (1991, 2000), Gauld et al. $(1997,2002)$ and authors' experience within the group. Naming of described species was not possible because of limited knowledge of the Brazilian fauna. Henceforward, morphospecies are referred here to as species.

To characterize the assemblage, we estimated richness (S), total (At) and relative (Ar) abundances, numbers of species represented by one and two individuals (singletons and doubletons) and number found in one and two samples (uniques and duplicates). The species accumulation curve was constructed using the Mao Tau method and the estimated richness was evaluated through the estimators Chao 1, Chao 2 (classic formula option for both), Jackknife 1, Jackknife 2, and Bootstrap with 500 randomizations. These analyses were performed using EstimateS 9.1.0 software (Colwell, 2013).

A rank-abundance curve on a logarithmic scale ( $\left.\log _{10}\right)$ was generated to evaluate dominance in the assemblage based on the abundance of species in all samples. The dominance indices of Simpson and Berger-Parker were calculated. The monthly number of collected species and individuals of Ophioniformes was correlated with meteorological data through the Coefficient of Pearson to search for possible relationships between the abiotic variables and the temporal distribution of species. The environmental data of mean temperature, relative humidity and precipitation were obtained from Instituto Nacional de Meteorologia (INMET). The data normality was assessed through the Shapiro-Wilk test and the abundance data were log transformed. These analyses were performed using PAST 4.02 software (Hammer et al., 2001).

High-resolution photographs were taken using a Leica M205C stereomicroscope attached to a Leica DFC 295 camera. Multiple photographs of the subject were taken at different focal stages and combined using multiple stack methods with Leica LAS (Leica Application Suite V3.6.0) or Helicon Focus 6.7.1 software.

\section{RESULTS}

A total of 2,331 specimens of Ichneumonidae were collected in our survey. From these, 621 specimens of Ophioniformes were identified in 11 subfamilies, 30 genera and 106 species (Tables 1 and 2). Nearly $70 \%$ of the specimens captured were identified as Campopleginae (8 genera and 29 species), Cremastinae ( 5 genera and 21 species) and Metopiinae (4 genera and 12 species). The most abundant Ophioniformes genera were Xiphosomella Szépligeti, 1905 (Cremastinae) ( $\mathrm{N}=97$ specimens), Mesochorus Gravenhorst, 1829 (Mesochorinae) ( $\mathrm{N}=96)$, Casinaria Holmgren, 1859 (Campopleginae) ( $\mathrm{N}=88$ ), Eiphosoma Cresson, 1865 (Cremastinae) $(\mathrm{N}=66)$ and Stethantyx Townes, 1971 (Tersilochinae) $(\mathrm{N}=61)$.

We recorded a pattern of a few relatively abundant Ophioniformes species and many rare ones: 40 

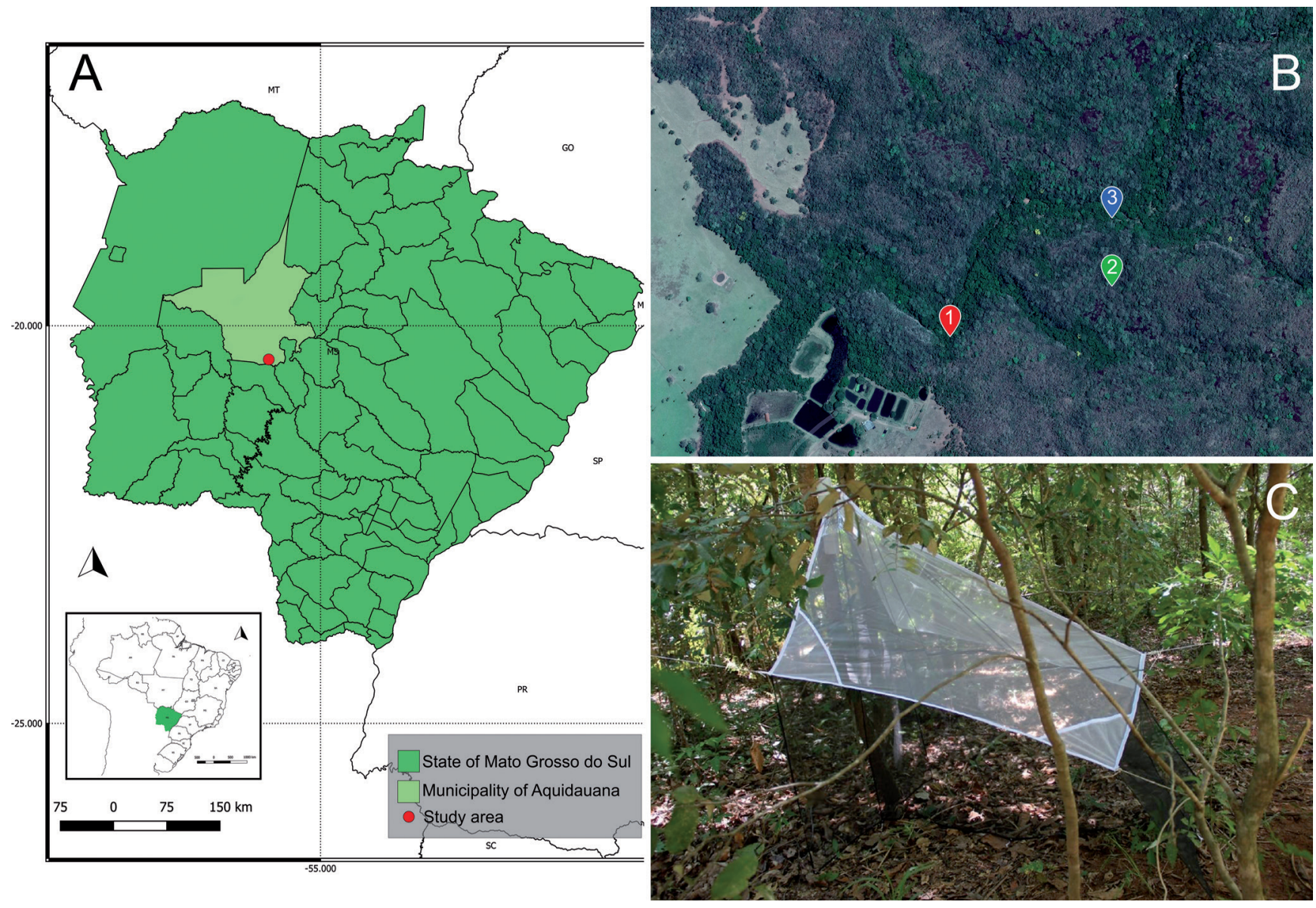

Figure 1. (A) Map illustrating the state of Mato Grosso do Sul (Brazil) emphasizing the Municipality of Aquidauana where the samples were collected. (B) Satellite image of the the Reserva Ecologica da Universidade Estadual do Mato Grosso do Sul showing the location where the Malaise traps have been deployed: $1=$ Riparian Forest; 2 = Seasonal Deciduous Forest with closed vegetation; 3 = Seasonal Deciduous Forest with open vegetation. (C) Malaise trap assembled in the Seasonal Deciduous Forest with open vegetation $\left(20^{\circ} 25^{\prime} 59.0^{\prime \prime} S, 55^{\circ} 39^{\prime} 20.8^{\prime \prime} \mathrm{W}\right)$.

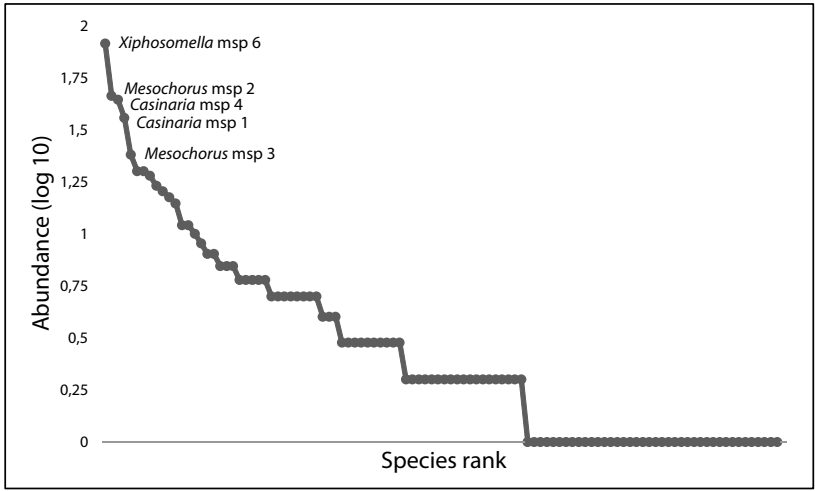

Figure 2. Rank-abundance curve and dominant species of the 0phioniformes collected in Aquidauana (MS), between September 2011 and August 2012.

singletons (37.7\%), 19 doubletons (18\%), 44 uniques (41.5\%) and 27 (25.4\%) duplicates. The low values obtained by the Simpson and Berger-Parker indices $(0.04$ and 0.13 , respectively) indicate the absence of species with significant relative higher dominance. The most dominant species, however, were Xiphosomella sp.6 (Fig. 5A), Mesochorus sp.2, Casinaria sp.4 and sp.1, and Mesochorus sp.3, which together accounted for $36.5 \%$ of the sampled specimens (Fig. 2).

The richest months for Ophioniformes records were August/2012 followed by September and October/2011.
Table 1. Total and relative abundance of Ophioniformes subfamilies (Hymenoptera: Ichneumonidae) collected in Aquidauana, MS, from September 2011 to August 2012.

\begin{tabular}{lcc}
\hline \multicolumn{1}{c}{ Ichneumonidae subfamilies } & Total abundance & Relative abundance \\
\hline Anomaloninae & 9 & $0.39 \%$ \\
Banchinae & 46 & $1.97 \%$ \\
Campopleginae & 157 & $6.74 \%$ \\
Cremastinae & 170 & $7.29 \%$ \\
Ctenopelmatinae & 1 & $0.04 \%$ \\
Mesochorinae & 96 & $4.12 \%$ \\
Metopinae & 42 & $1.80 \%$ \\
Nesomesochorinae & 6 & $0.26 \%$ \\
Ophioninae & 24 & $1.03 \%$ \\
Tersilochinae & 61 & $2.62 \%$ \\
Tryphoninae & 9 & $0.39 \%$ \\
Othersichneumonids & 1710 & $73.36 \%$ \\
\hline
\end{tabular}

Mesochorus sp. 3 was encountered in 11 months, followed by Xiphosomella sp.6 (9 months), and Stethantyx sp.6 (8 months) (Table 2).

The performance of species richness estimators varied, with Jackknife 2 estimating the greatest number of species (165.56) and Bootstrap being the most conservative, suggesting about $84 \%$ of the inventory of species completeness (Fig. 3, Table 3). 
Table 2. Composition, abundance and sampling months of Ophioniformes (Hymenoptera: Ichneumonidae) collected in Aquidauana, MS, from September 2011 to August 2012.

\begin{tabular}{|c|c|c|c|c|}
\hline \multirow{2}{*}{$\begin{array}{l}\text { Ichneumonidae } \\
\text { subfamilies }\end{array}$} & \multirow{2}{*}{$\begin{array}{c}\text { Total } \\
\text { abundance }\end{array}$} & \multirow{2}{*}{$\begin{array}{c}\text { Relative } \\
\text { abundance }\end{array}$} & \multicolumn{2}{|c|}{ Ocurrence months } \\
\hline & & & 2011 & 2012 \\
\hline \multicolumn{5}{|l|}{ Anomaloninae } \\
\hline Anomalon sp.1 & 1 & $0.16 \%$ & - & May \\
\hline Ophionellus sp.1 & 1 & $0.16 \%$ & - & Jun \\
\hline Ophiopterus sp.1 & 2 & $0.32 \%$ & Sep & Aug \\
\hline Podogaster sp.1 & 1 & $0.16 \%$ & - & Aug \\
\hline Podogaster sp.2 & 1 & $0.16 \%$ & - & Aug \\
\hline Podogaster sp.3 & 3 & $0.48 \%$ & - & Jan \\
\hline \multicolumn{5}{|l|}{ Banchinae } \\
\hline Diradops sp.1 & 4 & $0.64 \%$ & $0 c t$ & Jul-Aug \\
\hline Diradops sp.2 & 10 & $1.61 \%$ & Sep & Aug \\
\hline Diradops sp.3 & 1 & $0.16 \%$ & - & Aug \\
\hline Diradops sp.4 & 1 & $0.16 \%$ & Sep & Aug \\
\hline Meniscomorpha sp.1 & 4 & $0.64 \%$ & Sep & Aug \\
\hline Meniscomorpha sp.2 & 1 & $0.16 \%$ & - & Aug \\
\hline Meniscomorpha sp.3 & 1 & $0.16 \%$ & - & Aug \\
\hline Syzeuctus sp.1 & 19 & $3.06 \%$ & Sep-Nov & Mar, Jun-Aug \\
\hline Syzeuctus sp.2 & 5 & $0.81 \%$ & Nov-Dec & Aug \\
\hline \multicolumn{5}{|l|}{ Campopleginae } \\
\hline Casinaria sp.1 & 36 & $5.80 \%$ & Sep-Nov & May-Aug \\
\hline Casinaria sp.2 & 5 & $0.81 \%$ & - & Aug \\
\hline Casinaria sp.3 & 1 & $0.16 \%$ & Sep & - \\
\hline Casinaria sp.4 & 44 & $7.09 \%$ & Sep-Dec & Jun-Aug \\
\hline Casinaria sp. 5 & 2 & $0.32 \%$ & $0 c t$ & Aug \\
\hline Charops sp.1 & 2 & $0.32 \%$ & Nov & May \\
\hline Charops sp.2 & 1 & $0.16 \%$ & - & Aug \\
\hline Cryptophion sp.1 & 1 & $0.16 \%$ & Sep & - \\
\hline Diadegma sp.1 & 9 & $1.45 \%$ & Oct-Dec & Jun-Jul \\
\hline Dusona sp.1 & 1 & $0.16 \%$ & Sep & - \\
\hline Dusona sp.2 & 1 & $0.16 \%$ & Sep & - \\
\hline Dusona sp.3 & 3 & $0.48 \%$ & Sep & - \\
\hline Dusona sp.4 & 2 & $0.32 \%$ & - & Aug \\
\hline Dusona sp.5 & 4 & $0.64 \%$ & Sep & Aug \\
\hline Dusona sp.6 & 3 & $0.48 \%$ & Sep-0ct & - \\
\hline Dusona sp.7 & 1 & $0.16 \%$ & Sep & - \\
\hline Dusona sp. 8 & 6 & $0.97 \%$ & Sep-0ct & Jun-Aug \\
\hline Hyposoter sp.1 & 14 & $2.25 \%$ & Sep-0ct & Mar, May-Aug \\
\hline Hyposoter sp.2 & 1 & $0.16 \%$ & - & Jun \\
\hline Hyposoter sp.3 & 1 & $0.16 \%$ & - & Jun \\
\hline Hyposoter sp.4 & 1 & $0.16 \%$ & - & Aug \\
\hline Microcharops sp.1 & 1 & $0.16 \%$ & - & Aug \\
\hline Microcharops sp.2 & 2 & $0.32 \%$ & Sep & Aug \\
\hline Venturia sp.1 & 3 & $0.48 \%$ & $0 c t$ & May, Aug \\
\hline Venturia sp.2 & 1 & $0.16 \%$ & $0 c t$ & - \\
\hline Venturia sp. 3 & 2 & $0.32 \%$ & - & Jun, Aug \\
\hline Venturia sp.4 & 1 & $0.16 \%$ & Dec & - \\
\hline Venturia sp.5 & 2 & $0.32 \%$ & Sep & Aug \\
\hline Venturia sp.6 & 5 & $0.81 \%$ & Sep & May-Jul \\
\hline Venturia sp.7 & 1 & $0.16 \%$ & - & Jul \\
\hline \multicolumn{5}{|l|}{ Cremastinae } \\
\hline Dimophora sp.1 & 1 & $0.16 \%$ & - & Jul \\
\hline Dimophora sp.2 & 1 & $0.16 \%$ & $0 c t$ & - \\
\hline Dimophora sp.3 & 2 & $0.32 \%$ & - & Aug \\
\hline Eiphosoma sp.1 & 6 & $0.97 \%$ & Sep & Aug \\
\hline Eiphosoma sp.2 & 7 & $1.13 \%$ & Sep & Aug \\
\hline Eiphosoma sp.3 & 1 & $0.16 \%$ & - & Aug \\
\hline Eiphosoma sp.4 & 1 & $0.16 \%$ & $0 \mathrm{ct}$ & - \\
\hline Eiphosoma sp.5 & 7 & $1.13 \%$ & Sep-0ct & Aug \\
\hline Eiphosoma sp.6 & 3 & $0.48 \%$ & Sep & Aug \\
\hline
\end{tabular}

\begin{tabular}{|c|c|c|c|c|}
\hline \multirow{2}{*}{$\begin{array}{l}\text { Ichneumonidae } \\
\text { subfamilies }\end{array}$} & \multirow{2}{*}{$\begin{array}{c}\text { Total } \\
\text { abundance }\end{array}$} & \multirow{2}{*}{$\begin{array}{c}\text { Relative } \\
\text { abundance }\end{array}$} & \multicolumn{2}{|c|}{ Ocurrence months } \\
\hline & & & 2011 & 2012 \\
\hline Eiphosoma sp.7 & 6 & $0.97 \%$ & - & Aug \\
\hline Eiphosoma sp.8 & 17 & $2.74 \%$ & Sep-0ct & Mar, Jun, Aug \\
\hline Eiphosoma sp.9 & 15 & $2.42 \%$ & Sep-0ct & Jan, May, Jul-Aug \\
\hline Eiphosoma sp.10 & 3 & $0.48 \%$ & - & Jun, Aug \\
\hline Pristomerus sp.1 & 2 & $0.32 \%$ & $0 \mathrm{ct}$ & Aug \\
\hline Temelucha sp.1 & 1 & $0.16 \%$ & Sep & - \\
\hline Xiphosomella sp.1 & 1 & $0.16 \%$ & - & Jan \\
\hline Xiphosomella sp.2 & 1 & $0.16 \%$ & - & Aug \\
\hline Xiphosomella sp.3 & 1 & $0.16 \%$ & - & Aug \\
\hline Xiphosomella sp.4 & 5 & $0.81 \%$ & Sep, Dec & Jun, Aug \\
\hline Xiphosomella sp.5 & 7 & $1.13 \%$ & Sep-Nov & Jun, Aug \\
\hline Xiphosomella sp.6 & 82 & $13.20 \%$ & Sep-Dec & Feb, May-Aug \\
\hline \multicolumn{5}{|l|}{ Ctenopelmatinae } \\
\hline Physotarsus sp.1 & 1 & $0.16 \%$ & Sep & - \\
\hline \multicolumn{5}{|l|}{ Mesochorinae } \\
\hline Mesochorus sp.1 & 11 & $1.77 \%$ & Oct-Nov & May-Aug \\
\hline Mesochorus sp.2 & 46 & $7.41 \%$ & Sep-Nov & May-Aug \\
\hline Mesochorus sp.3 & 24 & $3.86 \%$ & Sep-Dec & Jan-May, Jul-Aug \\
\hline Mesochorus sp.4 & 8 & $1.29 \%$ & Oct-Dec & Feb, Jul-Aug \\
\hline Mesochorus sp.5 & 2 & $0.32 \%$ & $0 \mathrm{ct}$ & Feb \\
\hline Mesochorus sp. 6 & 5 & $0.81 \%$ & Oct-Nov & Feb, Jul \\
\hline \multicolumn{5}{|l|}{ Metopiinae } \\
\hline Colpotrochia sp.1 & 2 & $0.32 \%$ & Sep & - \\
\hline Colpotrochia sp.2 & 1 & $0.16 \%$ & Dec & - \\
\hline Colpotrochia sp.3 & 1 & $0.16 \%$ & - & Aug \\
\hline Colpotrochia sp.4 & 2 & $0.32 \%$ & - & Aug \\
\hline Colpotrochia sp.5 & 6 & $0.97 \%$ & Sep-0ct & Jun, Aug \\
\hline Colpotrochia sp.6 & 1 & $0.16 \%$ & Sep & - \\
\hline Colpotrochia sp.7 & 3 & $0.48 \%$ & - & Aug \\
\hline Exochus sp.1 & 20 & $3.22 \%$ & Sep-Dec & Jun \\
\hline Leurus sp.1 & 1 & $0.16 \%$ & & Aug \\
\hline Leurus sp.2 & 1 & $0.16 \%$ & Dec & - \\
\hline Trieces sp.1 & 3 & $0.48 \%$ & Nov-Dec & Feb \\
\hline Trieces sp.2 & 1 & $0.16 \%$ & Nov & - \\
\hline \multicolumn{5}{|l|}{ Nesomesochorinae } \\
\hline Nonnus sp.1 & 6 & $0.97 \%$ & Sep-0ct, Dec & - \\
\hline \multicolumn{5}{|l|}{ Ophioninae } \\
\hline Enicospilus sp.1 & 3 & $0.48 \%$ & Sep & - \\
\hline Enicospilus sp.2 & 1 & $0.16 \%$ & - & Aug \\
\hline Enicospilus sp.3 & 2 & $0.32 \%$ & - & Aug \\
\hline Enicospilus sp.4 & 3 & $0.48 \%$ & $0 \mathrm{ct}$ & Mar, Jun \\
\hline Enicospilus sp.5 & 2 & $0.32 \%$ & $0 \mathrm{ct}$ & Aug \\
\hline Enicospilus sp.6 & 2 & $0.32 \%$ & - & Mar, Aug \\
\hline Enicospilus sp.7 & 1 & $0.16 \%$ & - & Jul-Aug \\
\hline Enicospilus sp. 8 & 1 & $0.16 \%$ & - & Aug \\
\hline Enicospilus sp. 9 & 3 & $0.48 \%$ & - & Jun, Aug \\
\hline Enicospilus sp.10 & 5 & $0.81 \%$ & Sep, Dec & - \\
\hline Thyereodon sp.1 & 1 & $0.16 \%$ & $0 \mathrm{ct}$ & - \\
\hline \multicolumn{5}{|l|}{ Tersilochinae } \\
\hline Stethantyx sp.1 & 16 & $2.58 \%$ & Oct-Dec & Jan-Feb, Apr \\
\hline Stethantyx sp.2 & 1 & $0.16 \%$ & Nov & - \\
\hline Stethantyx sp.3 & 5 & $0.81 \%$ & Sep & Jun, Aug \\
\hline Stethantyx sp.4 & 11 & $1.77 \%$ & Oct-Dec & Jan-Feb \\
\hline Stethantyx sp.5 & 8 & $1.29 \%$ & Oct-Dec & Jan-Mar \\
\hline Stethantyx sp.6 & 20 & $3.22 \%$ & Oct-Dec & Jan-Apr, Jun \\
\hline \multicolumn{5}{|l|}{ Tryphoninae } \\
\hline Netelia sp.1 & 2 & $0.32 \%$ & - & Aug \\
\hline Netelia sp.2 & 2 & $0.32 \%$ & Sep & Jul \\
\hline Netelia sp.3 & 5 & $0.81 \%$ & - & Aug \\
\hline
\end{tabular}




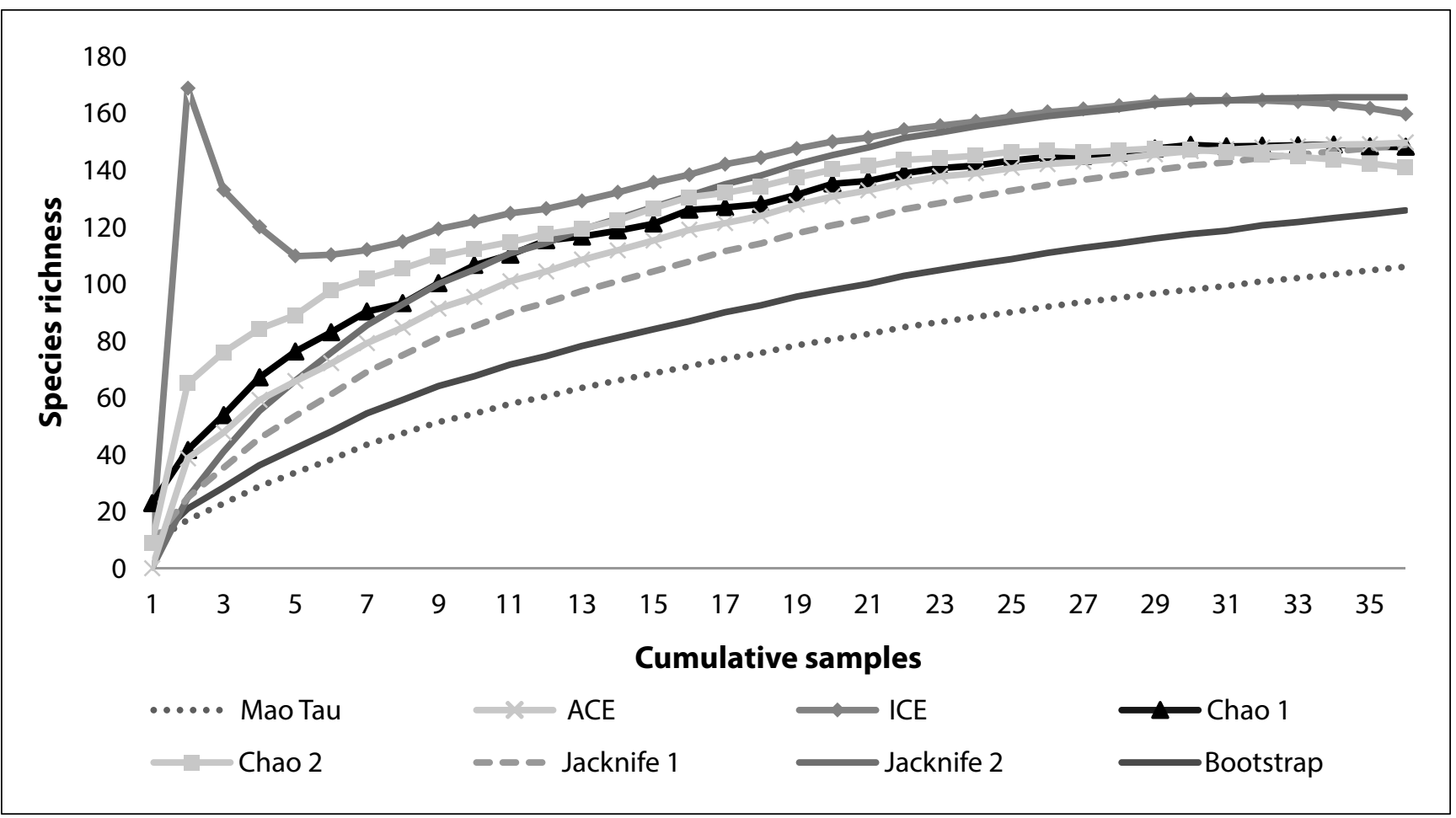

Figure 3. Observed richness and performance of the richness estimators of the Ophioniformes collected in Aquidauana (MS, Brazil), between September 2011 and August 2012.

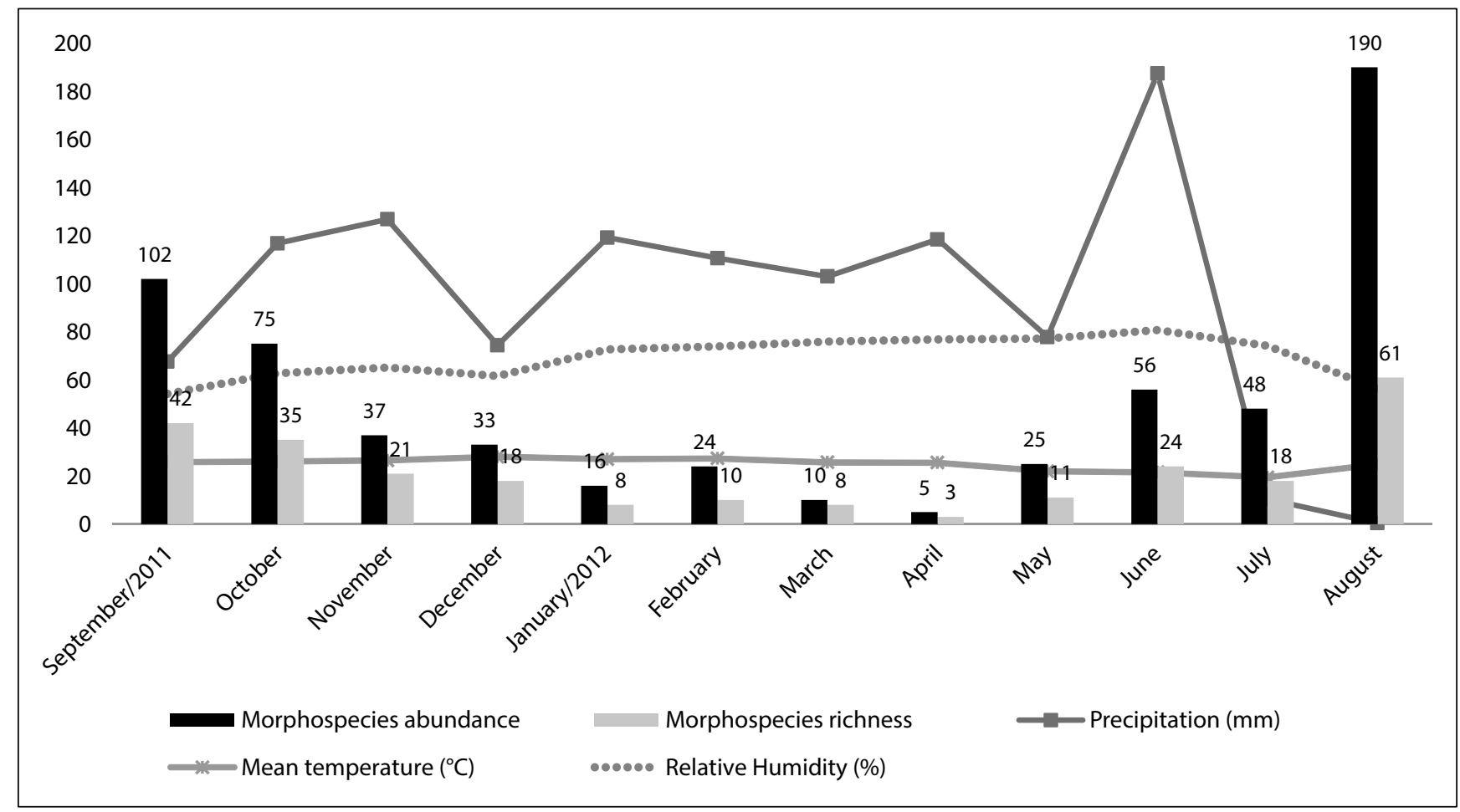

Figure 4. Distribution of environmental variables and abundance and species richness of Ophioniformes collected per month in Aquidauana (Mato Grosso do Sul, Brazil), between September 2011 and August 2012.

Among the climatic variables evaluated, relative humidity was the only variable negatively correlated with Ophioniformes abundance and richness (Table 4). The greatest richness also coincided with the period of higher abundance (Table 1 and Fig. 4) and the Pearson correlation test found a positive relation between richness and abundance variables $(\mathrm{RP}=0.91269, \mathrm{p}<0.05)$.

\section{DISCUSSION}

In this study, Ophioniformes accounted for $26,6 \%$ of overall Ichneumonidae collected in Aquidauana. Other previous studies indicate this group may represent 16\% to $50 \%$ of Ichneumonidae fauna collected in different regions of the country (Kumagai \& Graf, 2000; Kumagai, 
Table 3. Observed and estimated species richness of Ophioniformes collected in Aquidauana (MS), between September 2011 and August 2012.

\begin{tabular}{cccc}
\hline \multicolumn{2}{c}{ Estimators } & \multicolumn{2}{c}{ Estimators } \\
\hline Observed & 106 & Chao 2 & $140.86 \pm 13.8$ \\
ACE & 149.59 & Jacknife 1 & $148.78 \pm 11.17$ \\
ICE & 159.64 & Jacknife 2 & 165.56 \\
Cha0 1 & $148.04 \pm 17.66$ & Booststrap & 125.81 \\
\hline
\end{tabular}

Table 4. Pearson' linear correlation between environmental variables and abundance and richness of Ophioniformes species collected using Malaise traps in Aquidauana (MS), between September 2011 and August 2012. Asterisks $\left({ }^{*}\right)$ indicate statistical significance at level of 0.05 probability.

\begin{tabular}{lccc}
\hline & Mean temperature $\left({ }^{\circ} \mathrm{C}\right)$ & Precipitation $(\mathrm{mm})$ & Relative humidity (\%) \\
\hline Abundance & -0.18915 & -0.40245 & $-0.67064^{*}$ \\
Richness & -0.037404 & -0.44898 & $-0.77519^{*}$ \\
\hline
\end{tabular}

2002; Guerra \& Penteado-Dias, 2002; Kumagai \& Graf, 2002; Tanque et al., 2010; Comerio et al., 2012; Fernandes et al., 2019).

A relatively high number of Ophioniformes species were found in the present survey. Despite our efforts, rarefaction curves indicate an even greater actual richness, estimated between 125 to 165 species. The comparatively high number of singletons and uniques samples suggests the necessity of greater sampling efforts, as observed by Sääksjärvi et al. (2004) who recorded a relatively high local diversity of Pimplinae (Pimpliformes) in Amazonian Peru, but also represented by a relatively high number of singletons. Fernandes et al. (2017) pointed out the necessity of long-term sampling for the collection of rare specimens of the small family Sclerogibbidae. An interesting example can be observed in Supeleto et al. (2020): even after extensive collection trips, only six specimens of Acrosnemus Supeleto, Aguiar \& Santos, 2020 (Ichneumonidae: Cryptinae) were sampled showing the importance of recurrent sampling.

Among the Ophioniformes subfamilies collected, Nesomesochorinae is for the first time recorded in a Savanna area in Center-West Brazil. Although Lycorininae has not collected in our study, Shimbori et al. (2017) recorded the subfamily in the municipality of Campo Grande, only $140 \mathrm{~km}$ distant from Aquidauana.

It is well known that temperature and humidity are important factors regulating parasitoid life (e.g., Gauld, 1987; Ouedraogo et al., 1996; Emana, 2007). Our figures support Aranda \& Gracioli (2015) results that peak abundance in Hymenoptera in the Brazilian Savanna is from August to October (Table 2).

Anomaloninae is a subfamily currently with 25 species of nine genera recorded in Brazil (Fernandes et al., 2020a). Shimbori et al. (2017) recorded the presence of seven of the recorded Brazilian genera of this subfamily (except for Castrosion Gauld \& Bradshaw, 1997 and Ophiopterus Brullé, 1846) in the state of Mato Grosso do Sul. The genus Ophiopterus (Fig. 6B) is represented by two New World species: O. cincticornis (Cresson, 1865) known from USA to Panama and O. coarctatus Brullé, 1846 which is endemic to Brazil (Yu et al., 2016;
Fernandes et al., 2020a). O. coarctatus has been recorded in the Amazon (Morley, 1912), Guaratuba in its south region (Brullé, 1846) and in the state of Espírito Santo (Azevedo et al., 2015). The genus is recorded here for the first time in Central-West Brazil.

Five species of the cosmopolitan genus Anomalon Panzer, 1804 are recorded in Brazil (Yu et al., 2016; Fernandes et al., 2020a). Apart from the savanna this genus is also known to occur in the Amazon (Townes \& Townes, 1966) and Caatinga biomes (Fernandes et al., $2019,2020 b$ ) and in coconut palm and coffee crops (Melo et al., 2009; Comério et al., 2012). Ophionellus Westwood, 1874 is a small new world genus (21 species) with three Brazilian species (Yu et al., 2016; Fernandes et al., 2020a). Besides the records for Mato Grosso do Sul state, this genus has been recorded in the south by Brullé (1846) and in soy crops attacking the noctuid moths Chrysodeixis includens (Walker, 1858) and Heliothis virescens (Fabricius, 1777) (Massarolli et al., 2018).

The Neotropical genus Podogaster Brullé, 1846 with 26 known species, stands out by being relatively well documented in Brazil (Kumagai \& Graf, 2000; Melo et al., 2009; Azevedo et al., 2015). Eight species are recorded for the country (Yu et al., 2016; Fernandes et al., 2020a). Brazilian host records of this genus include Chrysodeixis includens (Walker, 1858) (Lepidoptera: Noctuidae) in soy crops (Massarolli et al., 2018) and Hypsipyla grandella (Zeller, 1848) (Lepidoptera: Pyralidae) in the south of Brazil (Graf, 1983).

The cosmopolitan Banchinae subfamily has 28 described species in 13 genera reported in Brazil (Yu et al., 2016; Fernandes et al., 2020a). All the genera found in this study are first records for the Central-West region of Brazil. Thirty-five species of Diradops Townes, 1946 (Fig. 5C) are restricted to the New World, two of them recorded in Brazil: Diradops castanea (Brullé, 1846) and Diradops aculate (Brullé, 1846) both occurring in the South (Brullé, 1846). The genus was well represented in our survey, with four species most frequently collected in August. Little biological information can be found in the literature, but they are known to attack Notodontidae and Noctuidae moths (Surgeoner \& Wallner, 1975; Kasparyan \& Ruíz, 2007; Fernandes et al., 2010).

Meniscomorpha Schmiedeknecht, 1907 (Fig. 5D) is also a New World genus with 64 described species including four in Brazil (Yu et al., 2016; Fernandes et al., 2020a). Members of this genus were recorded attacking Gelechiidae and Oecophoridae moths in Southeast Brazil (Fernandes et al., 2010; Nava et al., 2005). Syzeuctus Förster, 1869 (Fig. 6A) is a large cosmopolitan genus comprising 127 valid nominal species (Yu et al., 2016). In Brazil only Syzeuctus minasensis (Brèthes, 1927) has been recorded. Its occurrence was documented in the Southeast region (Brèthes, 1927) without host record.

The subfamily Campopleginae stands-out by the relatively high abundance and richness recorded. The incidence of this subfamily may be associated with the agricultural areas surrounding the study site. Campopleginae play an important role as a biocontrol agent against crop pests (e.g., Moraes et al., 1991; Azidah et al., 2000; 
Bortolotto et al., 2014). All genera identified in this study were also found occurring in organic crops in the State of São Paulo by Sandonato et al. (2010).

Casinaria is a large genus with 100 species worldwide (Yu et al., 2016) and only three of them are recorded in Brazil: C. bonaerensis (Schrottky, 1902), C. brasiliensis Brèthes, 1927, C. plusiae (Blanchard, 1947) (Yu et al., 2016; Fernandes et al., 2020a). The last species was identified attacking the noctuid moths Rachiplusia nu (Guenée, 1852) and Chrysodeixis includens (Walker, 1858) in Brazilian soy crops by Moraes et al. (1991).

The genus Charops Holmgren, 1859 represented here by two species was recently reviewed by Santos et al. (2019) for Brazil, with the description of seven species. Marconato et al. (2008) found this genus attacking geometrid moths in Erythroxylum microphyllum St.-Hilaire, a plant species typical of the Brazilian Savanna (Mendonça et al., 1998). As rare as Charops, Cryptophion Viereck, 1913 was represented by only one specimen collected in September. The works of Onody et al. (2013) and Onody \& Penteado-Dias (2016) were important contributions for the taxonomy and biogeography of this genus, showing its presence in the Atlantic forest and Savanna in the Brazilian southeast. Gauld \& Janzen (1994) observed specimens reared from the sphingid moth Erinnyis ello (Linnaeus, 1758) in Costa Rica. Besides Sphingidae, this genus is also known to attack saturniid moths (Gauld \& Janzen, 1994).

Diadegma Förster, 1869 is represented in Brazil by D. imbecillum (Enderlein, 1921) in the South region and D. leontiniae (Brèthes, 1923) in South and Central-West regions (Townes \& Townes, 1966; Wagener et al., 2006). $D$. leontiniae is an important biological control agent of Plutella xylostella (Linnaeus, 1758) (Lepidoptera: Plutellidae), one of the most damaging pests of cruciferous plants (Azidah et al., 2000). This genus is recorded for the first time in Mato Grosso do Sul state.

A relatively high richness and abundance were observed for Dusona Cameron, 1901 in our survey. Kumagai \& Graf (2000) observed four Dusona species occurring in rural and urban area in the South of Brazil. This genus has more than 400 described species worldwide and only four of them have been recorded in Brazil. The last Brazilian species was described in 1926 (Hancock, 1926).

Similar to Campopleginae, members of Cremastinae are parasitoids mostly of Lepidoptera, but also Coleoptera (Gauld, 2000; Quicke, 2015), including many important crop pests. For instance, Silva et al., (2012) reported Eiphosoma laphygmae Costa Lima, 1953 attacking Spodoptera frugiperda (Smith, 1797) (Lepidoptera: Noctuidae) in maize crops].

Eiphosoma was the most common genus of this subfamily in our survey. Onody et al. (2012) reported fourteen Eiphosoma species occurring in organic crops in the state of São Paulo. Seven species of this genus were reported in a Savanna fragment situated in the same state (Melo \& Penteado-Dias, 2009). This is a medium-sized genus with 56 valid nominal species restricted to the New World, with 23 species recorded in Brazil (Yu et al., 2016; Fernandes et al., 2020a). Shimbori et al. (2017) re- corded five species for the Mato Grosso do Sul state. Species of this genus are known to be endoparasitoids of Lepidoptera with host records of the families Crambidae, Noctuidae and Pyralidae in Brazil (Sauer, 1946; Lima, 1953).

Little is known about the genus Dimophora Förster, 1869 in Brazil. This small genus includes 19 described species, but only one from the Neotropical region: Dimophora daschi Gauld, 2000 described from Costa Rica (Yu et al., 2016). The presence of this genus was reported by Azevedo et al. (2015) in Espírito Santo state. We record this genus for the first time in the Brazilian Central-West region.

Pristomerus Curtis, 1836 is a cosmopolitan, relatively large genus comprising 140 valid nominal species (Yu et al., 2016). Pristomerus spinator (Fabricius, 1804) is the only species occurring in Brazil. Patel \& Habib (1984) recorded this species attacking Spodoptera frugiperda (Smith, 1797) in corn crops in the Southeast region. Temelucha Förster, 1869 is also a cosmopolitan genus comprising 235 species with fourteen of them are known to occur in the Neotropics (Yu et al., 2016). Although no described species have been previously recorded in Brazil, the genus has been documented in different regions including the Northeast (Fernandes et al., 2019), Southeast (Azevedo et al., 2015) and for the first time hereby in Central-West region.

The New World genus Xiphosomella has 54 described species (Yu et al., 2016). Four species are known to occur in the North, Southeast and South Brazilian regions (Lima, 1954; Azevedo et al., 2015; Fernandes et al., 2020a). Biological records of this genus are scarce. Cushman (1924) recorded X. stenomae Cushman, 1924 attacking the Depressariidae moth Stenoma catenifer Walsingham, 1912 in Panama. In Brazil, the genus is recorded as a parasitoid of the concealer moth Cerconota anonella (Sepp, 1830) (Depressariidae) in soursop (Micheletti \& Filho, 2000).

The subfamily Ctenopelmatinae was represented in our survey by only one specimen of the New World genus Physotarsus Townes, 1966 collected only in September. Six species are known to occur in Brazil (Zhaurova \& Wharton, 2009). This genus has been recorded as parasitoid of Trochophora lobata (Erichson, 1848), a sawfly of the family Argidae in Costa Rica (Gauld et al., 1997).

Mesochorinae are currently classified in 10 genera (Araujo et al., 2018; Araujo, 2018) with 871 described species (Yu et al., 2016). From these, 700 species belong to the cosmopolitan genus Mesochorus (Fig. 5F) with 49 species recorded in Brazil (Araujo et al., 2019). Most of these species were described by Dasch in 1974 and are endemic to the Atlantic Forest, while only one is described for the Savanna biome (Araujo et al., 2019). Members of this genus are hyperparasitoids mostly of Ichneumonoidea (occasionally Diptera: Tachinidae) within Lepidoptera and sawfly larvae and also in immature Hemiptera (Quicke, 2015 and references therein). The six species we found are likely undescribed since the number of Mesochorus species is probably underestimated, as already pointed out by Araujo et al. (2019). 

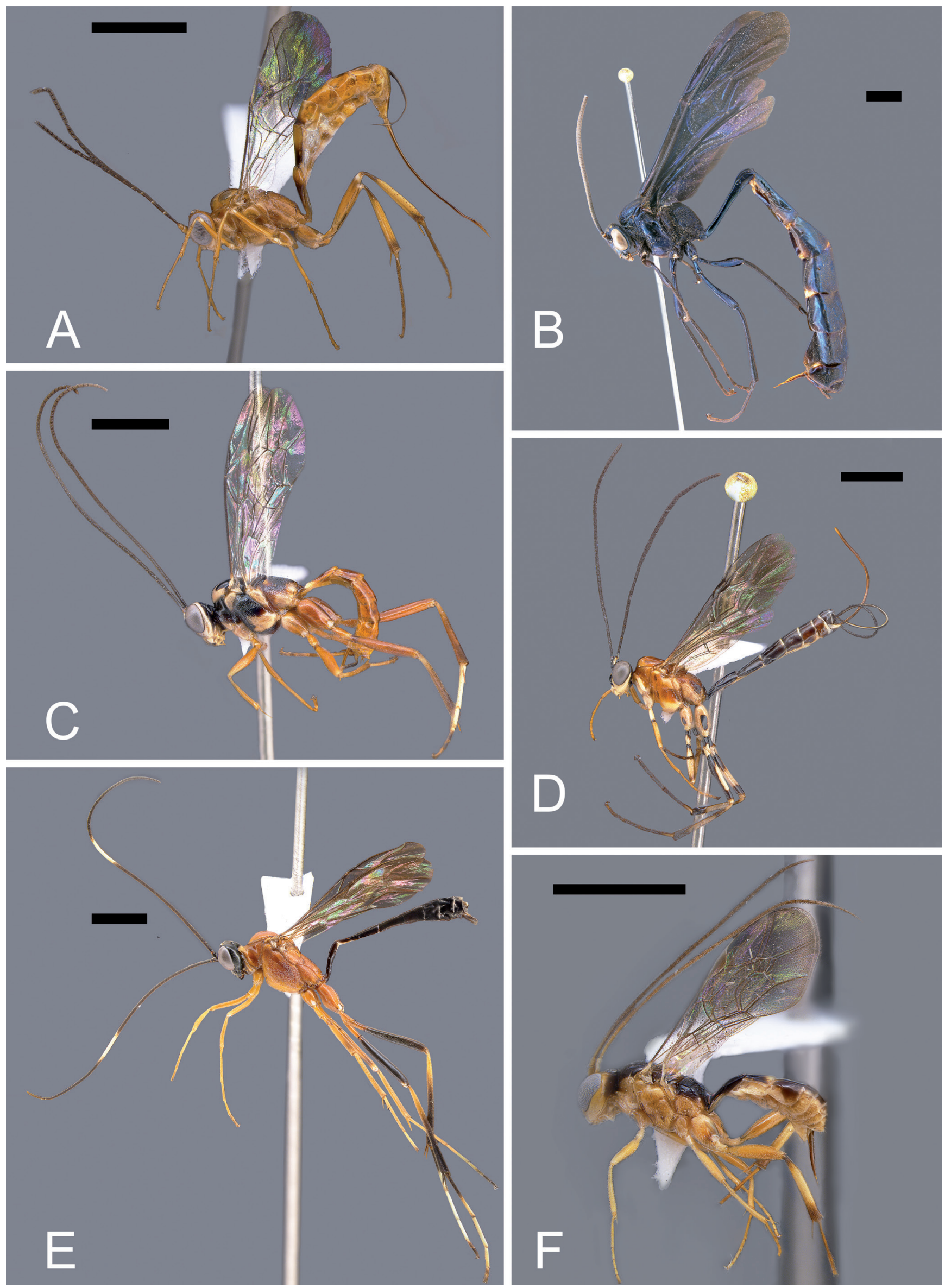

Figure 5. (A) Xiphosomella sp.6 (Cremastinae) female habitus, (B) Thyreodon sp.1 (Ophioninae) female habitus, (C) Diradops sp.4 (Banchinae) female habitus, (D) Meniscomorpha sp.1 (Banchinae) female habitus, (E) Nonnus sp.1 (Nesomesochorinae) female habitus, (F) Mesochorus sp.1 (Mesochorinae) female habitus. Scale bars: A-E: 2 mm, F: 1 mm. Specimens collected in Aquidauana, MS, between September 2011 and August 2012. 

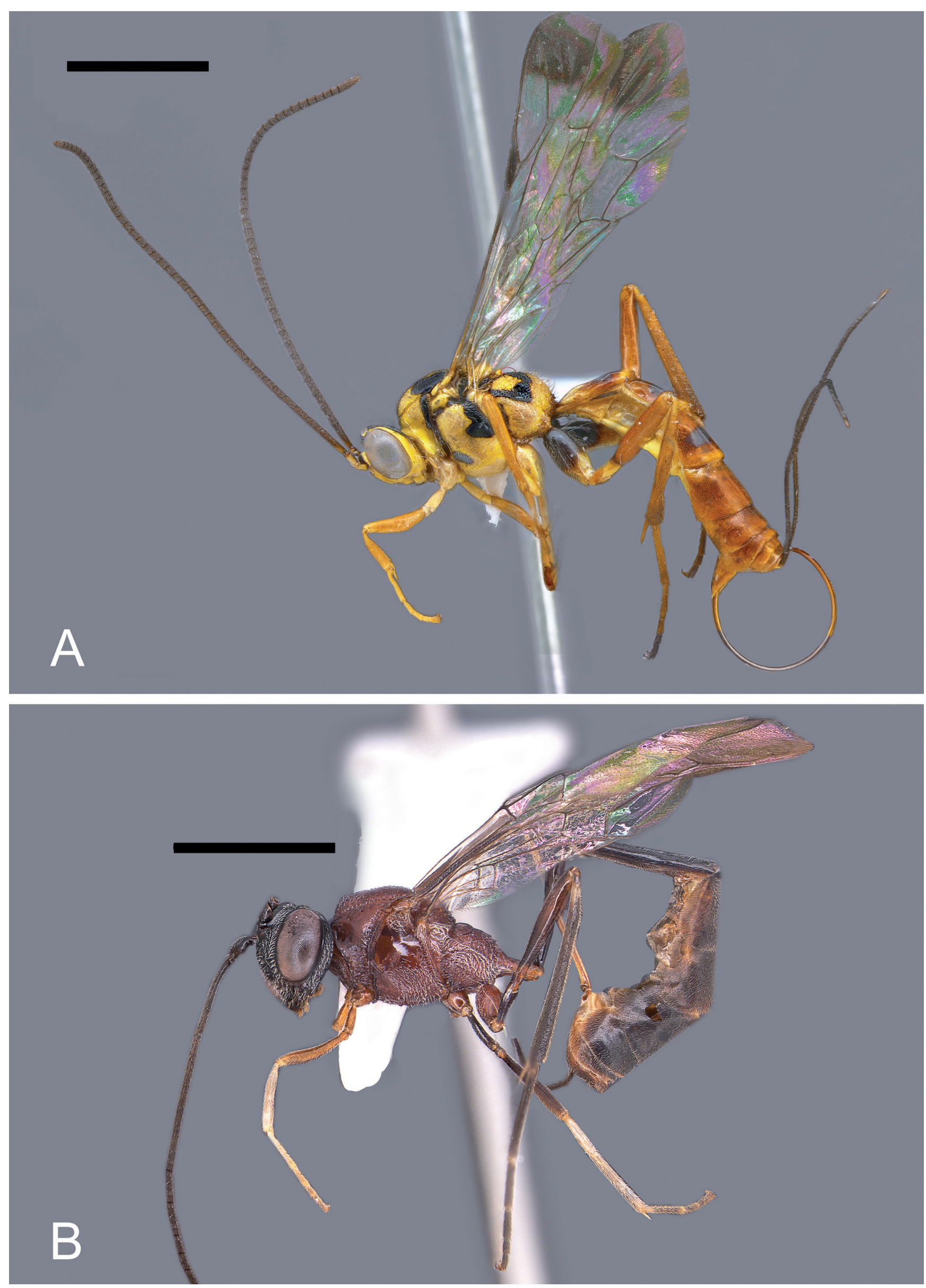

Figure 6. (A) Syzeuctus sp.1 (Banchinae) female habitus, (B) Ophiopterus sp.1 (Anomaloninae) female habitus. Scale bars: 2 mm. Specimens collected in Aquidauana, MS, between September 2011 and August 2012. 
Metopiinae is a medium-sized cosmopolitan subfamily with 862 described species worldwide (Yu et al., 2016). Fernandes et al. (2020a) registered nine genera and 29 species occurring in all regions of Brazil (apart from the Northeast) of Brazil. The genus Colpotrochia Holmgren, 1856 comprises 62 species with five Brazilian species. This genus was recorded parasitizing Spodoptera frugiperda (Smith, 1797) in Brazilian corn fields (Silva et al., 2012).

Exochus Gravenhorst, 1829 is a large genus comprising 281 cosmopolitan species (Yu et al., 2016). This genus was studied recently in Brazil by Melo et al. (2015), who described E. atlanticus from the Atlantic rainforest and provide new geographical records of E. ablatus Gauld \& Sithole, 2002 and E. izbus Gauld \& Sithole, 2002 in Savanna and semideciduous forest in southeast region.

Leurus Townes, 1946 is a small new world genus with eleven descried species (Yu et al., 2016). Leusus caeruliventris (Cresson, 1868) is the only specie recorded from Brazil thus far. Fernandes et al. (2010) recorded this species attacking Dichomeris sp. (Gelechiidae) and Leurus sp. parasitizing Olethreutinae sp. (Tortricidae) on Croton floribundus Spreng in southeast region. Trieces Townes, 1946 is a medium-sized cosmopolitan genus with 70 valid species (Yu et al., 2016). Ten species were recorded in Brazil, with most occurring in the Southeast region (Fernandes et al., 2020a).

Wasps belonging to the New World genus Nonnus Cresson, 1874 (Fig. 5E) were the only representatives of the subfamily Nesomesochorinae in our survey. Its members are relatively large and conspicuous wasps with 20 described species (Wahl \& Bennett, 2020). Nine species are recorded in the Brazilian states of Amazonas, Espírito Santo, Goiás, Mato Grosso, Rio de Janeiro, Rio Grande do Sul and São Paulo (Townes \& Townes, 1966; Comério et al., 2012; Azevedo et al., 2015; Fernandes et al., 2020a) and for the first time here for Mato Grosso do Sul state. Host records are unknown for Nonnus, thus the biology of this group remains a mystery (Wahl \& Bennett, 2020).

Ophioninae wasps are commonly collected in Brazil due to their large size and attraction to light (Burbutis \& James, 1979). This cosmopolitan subfamily comprises 32 genera and more than one thousand species (Yu et al., 2016). Some species of this subfamily are parasitoids of important agricultural pests (like $S$. frugiperda), but they are not suitable for biocontrol release programmes (Quicke, 2015). Most species of this subfamily belong to Enicospilus Stephens, 1835 which comprises around 700 species (Yu et al., 2016) with 61 of them recorded in all Brazilian regions (Fernandes et al., 2020a). We record here for the first time the genus Thyreodon Brullé, 1846 (Fig. 5B) in the Central-West Brazilian region. This genus comprises 45 species, nine of them with Brazilian occurrence (Yu et al., 2016; Fernandes et al., 2020a).

Tersilochinae is a cosmopolitan medium-sized subfamily with more than 560 described species in 27 genera (Khalaim \& Ruíz-Cancino, 2020). Fernandes et al. (2020a) registered three genera and 13 described species in the south and southeast regions of Brazil. Stethantyx Townes, 1971 is a Neartic and Neotropical genus with 47 species
(Yu et al., 2016). Recently taxonomic contributions to this genus were made by Khalaim (2017) with the description of Stethantyx durrelli Khalaim, 2017, increasing the recorded species in Brazil to 11 (Fernandes et al., 2020a). Biological information regarding this genus is scarce but it seems to parasitize weevils (Parker et al., 1950).

The subfamily Tryphoninae is a cosmopolitan group with 54 genera and about 1,300 species (Bennett, 2015). They are koinobiont ectoparasitoids of Lepidoptera larvae and pre-pupae (Konishi, 2014). In our survey this subfamily is represented by several species of the genus Netelia Gray, 1860, a large genus comprising more than 330 species, (Bennett, 2015), of which only nine are known to occur in Brazil (Yu et al., 2016); the most recent description being $N$. oeceticola (Blanchard, 1941), but the total number of species present might be much higher (Bennett, pers. comm.) This genus was recorded as a parasitoid of the noctuid moth Mocis latipes (Guenée, 1852) in the Southeast region (Lourenção et al., 1982).

In summary, this study recorded for the first time the presence of the genera Diadegma (Campopleginae) and Nonnus (Nesomesochorinae) for the Mato Grosso do Sul state and the genera Diradops, Meniscomorpha, Syzeuctus (all Banchinae), Ophiopterus (Anomaloninae) and Thyreodon (Ophioninae) for the Central-West region. Many genera recorded here (e.g., Dusona, Diradops, Enicospilus, Netelia) are relatively little-studied in the Neotropical region and the number of undescribed species in these genera highlights the huge unstudied species richness of Ichneumonidae Ophioninae wasps in Brazil and the need to study and conserve this critically important part of the world's biodiversity.

\section{ACKNOWLEDGMENTS}

We are grateful for Dr. Carlos Lamas for providing us with the Ophioniformes specimens collected by the project "Diptera from Mato Grosso, Mato Grosso do Sul and Rondônia states: diversity, systematics and distributional limits" (FAPESP Process 2010/52314-0 and CNPq Process 563256/2010-9), to Dr. Gavin R. Broad for helping in the identification of the genus Hyposoter. To Dr. Kelli S. Ramos, Dr. Paola L. Dall'Occo, Ms Joudellys Andrade-Silva and the two reviewers for their thoughtful suggestions on drafts of the manuscript. This work was supported by joint grants from Coordenação de Aperfeiçoamento de Pessoal de Nível Superior (CAPES) [88887.302820/2018-00], Conselho Nacional de Desenvolvimento Científico e Tecnológico (CNPq) [150713/2010-0, 440574/2015-3] and by Fundação de Amparo à Pesquisa do Estado de São Paulo (FAPESP) [2016/50378-8, 2017/07366-1].

\section{AUTHORS' CONTRIBUTIONS}

Conceived the study: A.D.S., H.C.O., C.R.F.B. Species identification and analysis: A.D.S., H.C.O. Images: A.D.S. Writing, review and editing: A.D.S., H.C.O., C.R.F.B. 


\section{REFERENCES}

Alvares, C.A.; Stape, J.L.; Sentelhas, P.C.; Moraes, G.; Leonardo, J. \& Sparovek, G. 2013. Köppn's climate classification map for Brazil. Meteorologische Zeitschrift, 22(6): 711-728. DOI

Aranda, R. \& Graciolli, G. 2015. Spatial-temporal distribution of the Hymenoptera in the Brazilian Savanna and the effects of habitat heterogeneity on these patterns. Journal of Insect Conservation, 19(6): 1173-1187. DOI

Araujo, R.0. 2018. Taxonomic notes and corrigendum for the manuscript entitled "Ichneumonid wasps of the subfamily Mesochorinae (Hymenoptera: Ichneumonidae): new replacement names, combinations and an updated key to the World genera" Araujo et al. (2018), Zootaxa, 4521: 052-060. Zootaxa, 4527(2): 292-294. DOl

Araujo, R.0.; Garrido, R.; Neto, J.N.M. \& Monzón, V.H. 2019. Real and potential distribution of the hyperparasitoid genus Mesochorus Gravenhorst (Ichneumonidae: Mesochorinae) in Brazil. Gayana, 83(2): 135-140. D0I

Araujo, R.0.; Vivallo, F. \& Santos, B.F. 2018. Ichneumonid wasps of the subfamily Mesochorinae: new replacement names, combinations and an updated key to the World genera (Hymenoptera: Ichneumonidae). Zootaxa, 4521(1): 52-60.

Azevedo, C.O.; Molin, A.D.; Macedo, A.C.C.; Penteado-Dias, A.M.; Rodriguez, V.B.; Dias, B.Z.K.; Waichert, C.; Aquino, D.; Smith, D.R.; Shimbori, E.M.; Noll, F.B.;Gibson, G.; Onody, H.C.; Carpenter, J.M.; Lattke, J.E.; Ramos, K.S.; Williams, K.; Masner, L.; Kimsey, L.S.; Tavares, M.T.; Olmi, M.; Buffington, M.L.; Ohl, M.; Sharkey, M.; Johnson, N.F.; Kawada, R.; Goncalves, R.B.; Feitosa, R.M.; Heydon, S.; Guerra, T.M.; Silva, T.S.R. \& Costa V. 2015. Checklist of the genera of Hymenoptera (Insecta) from Espírito Santo, Brazil. Boletim do Museu de Biologia Mello Leitão, 37(3): 313-343.

Azidah, A.A.; Fitton, M.G. \& Quicke, D.L.J. 2000. Identification of the Diadegma species (Hymenoptera: Ichneumonidae, Campopleginae) attacking the diamondback moth, Plutella xylostella (Lepidoptera: Plutellidae). Bulletin of Entomological Research, 90(5): 375-389. D0l

Bennett, A.M. 2015. Revision of the world genera of Tryphoninae (Hymenoptera: Ichneumonidae). American Entomological Institute, 86: 1-387.

Bennett, A.M.; Cardinal, S.; Gauld, I.D. \& Wahl, D.B. 2019. Phylogeny of the subfamilies of Ichneumonidae (Hymenoptera). Journal of Hymenoptera Research, 71(1): 1-157. DOI

Bortolotto, 0.C.; Menezes, A.D.O.; Hoshino, A.T.; Carvalho, M.G.; PomariFernandes, A. \& Salgado-Neto, G. 2014. Sugar solution treatment to attract natural enemies and its impact on fall armyworm Spodoptera frugiperda in maize fields. Interciencia, 39(6): 416-421.

Brèthes, J. 1927. Hyménoptères sud-américains du Deutsches Entomologisches Institut: Terebrantia. (Schluss). Entomologische Mitteilungen, 16: 319-335.

Brullé, M.A. 1846. Tome Quatrième. Des Hyménoptères. Les Ichneumonides. In: Lepeletier de Saint-Fargeau. A Histoire Naturelles des Insectes. Paris. p. 56-521.

Burbutis, P.P. \& James, A.S. 1979. Blacklight trap collecting of parasitic Hymenoptera. Entomological News, 90(1): 17-22.

Colli, G.R.; Vieira, C.R. \& Dianese, J.C. 2020. Biodiversity and conservation of the Cerrado: recent advances and old challenges. Biodiversity and Conservation, 29(5): 1465-1475. (Edição especial S1)

Colwell, R.K. 2013. EstimateS: Statistical estimation of species richness and shared species from samples. Version 9. User's Guide and application Available: http://purl.oclc.org/estimates.

Comério, E.F.; Onody, H.C. \& Benassi, V.L.R.M. 2012. Levantamento da fauna de Ichneumonidae (Hymenoptera) em cultivo de coqueiro anão verde associado a plantas invasoras. EntomoBrasilis, 5(2): 109-114.
Cushman, R.A. 1924. New genera and species of Ichneumon-flies. Proceedings of the United States National Museum, 64(2494): 1-16.

Dasch, C.E. 1974. Neotropic Mesochorinae (Hymenoptera: Ichneumonidae). Memoirs of the American Entomological Institute, 22: 1-509.

Emana, G.D. 2007. Comparative studies of the influence of relative humidity and temperature on the longevity and fecundity of the parasitoid, Cotesia flavipes. Journal of Insect Science, 7(1): 1-7. DOI

Enderlein, G. 1921. Beiträge zur Kenntnis aussereuropäischer Ichneumoniden V. Über die Familie Ophionidae. Stettiner Entomologische Zeitung, 82: 3-45.

Fernandes, D.R.R.; Alves, F.P.; Shimbori, E.M.; Lara, R.I.R.; Junior, J.C.S. \& Perioto, N.W. 2017. New distribution records of Sclerogibbidae (Hymenoptera: Chrysidoidea) in Brazil. EntomoBrasilis, 10(1): 33-36. D0l

Fernandes, D.R.R.; Santos, B.F.; Pádua, D.G. \& Araujo, R.0. 2020a. Ichneumonidae. In: Catálogo taxonômico da fauna do Brasil. PNUD. Available: http://fauna.jbri.gov.br. Access: 28/04/2020.

Fernandes, D.R.R.; Antunes, N.T.B.; Araujo, E.L.; Lara, R.I.R. \& Perioto, N.W. 2020b. Hymenoptera fauna, with emphasis on Ichneumonidae from an area of Caatinga in Northeast Brazil. EntomoBrasilis, 13: 1-7 DOI

Fernandes, D.R.R.;Santos, J.J.M.; Lara, R.I.R.;Silva, J.C.; Ferreira, H.A.\& Perioto, N.W. 2019. Fauna de Ichneumonidae (Hymenoptera: Ichneumonoidea) em áreas de Caatinga do Sudoeste da Bahia, Brasil. EntomoBrasilis, 12(3): 126-131. DOI

Fernandes, L.B.D.R.; Dias-Filho, M.M.; Fernandes, M.A. \& Penteado-Dias, A.M. 2010. Ichneumonidae (Hymenoptera) parasitoids of Lepidoptera caterpillars feeding on Croton floribundus Spreng (Euphorbiaceae). Revista Brasileira de Entomologia, 54(2): 263-269.

Gauld, I.D. 1987. Some factors affecting the composition of tropical ichneumonid faunas. Biological Journal of the Linnean Society, 30(4): 299-312. DOI

Gauld, I.D. 1991. The Ichneumonidae of Costa Rica, 1. Introduction, keys to subfamilies, and keys to the species of the lower Pimpliform subfamilies Rhyssinae, Poemeniinae, Acaenitinae and Cylloceriinae. Memoirs of the American Entomological Institute, 47: 1-589.

Gauld, I.D. 2000. The Ichneumonidae of Costa Rica, 3. Introduction and keys to species of the subfamilies Brachycyrtinae, Cremastinae, Labeninae and Oxytorinae, with an appendix on the Anomaloninae. Memoirs of the American Entomological Institute, 63: 1-453.

Gauld, I.D. \& Janzen, D.H. 1994. The classification, evolution, and biology of the Costa Rican species of Cryptophion (Hymenoptera: Ichneumonidae). Zoological Journal of the Linnean Society, 110(4): 297-324.

Gauld, I.D.; Sithole, R.; Ugalde Gómez, J.A. \& Godoy, C. 2002. The Ichneumonidae of Costa Rica, 4. Introduction and keys to species of the subfamilies Metopiinae and Banchinae. Memoirs of the American Entomological Institute, 66: 1-768.

Gauld, I.D.; Wahl, D.; Bradshaw, K.; Hanson, P. \& Ward, S. 1997. The Ichneumonidae of Costa Rica, 2. Introduction and keys to species of the smaller subfamilies, Anomaloninae, Ctenopelmatinae, Diplazontinae, Lycorininae, Phrudinae, Tryphoninae (excluding Netelia) and Xoridinae, with appendices on the Rhyssinae, and with a cladistic analysis of the genera and subgenera of Xoridinae. Memoirs of the American Entomological Institute, 57: 1-485.

Gómez, I.C.; Sääksjärvi, I.E.; Mayhew, P.J.; Pollet, M.; Rey del Castillo, C.; Nieves-Aldrey, J.L. \& Tuomisto, H. 2018. Variation in the species richness of parasitoid wasps (Ichneumonidae: Pimplinae and Rhyssinae) across sites on different continents. Insect Conservation and Diversity, 11(3): 305-316. DOI

Graf, V. 1983. Ichneumofauna do sudeste e sul do Brasil. 5. Nova espécie de Philodrymus (Anomaloninae, Hymenoptera). Contributions to the American Entomological Institute, 20: 398-401. 
Guerra, T.M. \& Penteado-Dias, A.M. 2002. Abundância de Ichneumonidae (Hymenoptera) em área de mata em São Carlos, Estado de São Paulo, Brasil. Acta Scientiarum. Biological Sciences, 24: 363-368.

Gupta, V.K. 1991. The parasitic Hymenoptera and biological control of the African Ichneumonidae. International Journal of Tropical Insect Science, 12: 9-18. DOI

Hammer, Ø.; Harper, D.A.T. \& Ryan P.D. 2001. PAST: Paleontological Statistics Software Package for Education and Data Analysis. Palaeontologia Electronica, 4(1): 1-9.

Hancock, G.L.R. 1926. A winter entomological visit to central Brazil. Entomologist, 59(754): 188-194.

Instituto Brasileiro de Geografia e Estatística (IBGE). 2019. Biomas e sistema costeiro-marinho do Brasil: compatível com a escala 1:250.000/IBGE, Coordenação de Recursos Naturais e Estudos Ambientais. IBGE, Rio de Janeiro. Relatórios Metodológicos, 45: 1-168.

Kasparyan, D.R. \& Ruíz, C.E. 2007. Review of Mexican species of Diradops Townes, with a key and description of a new species (Hymenoptera: Ichneumonidae: Banchinae). Zoosystematica Rossica, 16(2): 263-268.

Khalaim, A.I. 2017. Contribution to the study of the genus Stethantyx Townes (Hymenoptera, Ichneumonidae, Tersilochinae), with the description of a new species from Brazil. Journal of Hymenoptera Research, 55: 129-138. DOI

Khalaim, A.I. \& Ruíz-Cancino, E. 2020. Contribution to the taxonomy of Mexican Tersilochinae (Hymenoptera, Ichneumonidae), with descriptions of five new species. ZooKeys, 974: 1-21. DOI

Klopfstein, S.; Santos, B.F.; Shaw, M.R.; Alvarado, M.; Bennett, A.M.; Dal Pos, D.; Giannotta, M.; Herrera Florez, A.F.; Karlsson, D.; Khalaim, A.I.; Lima, A.R.; Mikó, I.; Sääksjärvi, I.E.; Shimizu, S.; Spasojevic, T.; van Noort, S.; Vilhelmsen, L. \& Broad, G.R. 2019. Darwin wasps: a new name heralds renewed efforts to unravel the evolutionary history of Ichneumonidae. Entomological Communications, 1: ec01006. D0I

Konishi, K. 2014. A revision of the subgenus Bessobates of the genus Netelia from Japan (Hymenoptera, Ichneumonidae, Tryphoninae). Zootaxa, 3755(4): 301-346.

Kumagai, A.F. 2002. Os Ichneumonidae (Hymenoptera) da Estação Ecológica da Universidade Federal de Minas Gerais, Belo Horizonte, com ênfase nas espécies de Pimplinae. Revista Brasileira de Entomologia, 46(2): 189-194. DOI

Kumagai, A.F. \& Graf, V. 2000. Ichneumonidae (Hymenoptera) de áreas urbana e rural de Curitiba, Paraná, Brasil. Acta Biológica Paranaense, 29(1-4): 153-168.

Kumagai, A.F. \& Graf, V. 2002. Biodiversidade de Ichneumonidae (Hymenoptera) e monitoramento das espécies de Pimplinae e Poemeniinae do Capão da Imbuia, Curitiba, Paraná. Revista Brasileira de Zoologia, 19(2): 445-452. D0I

Lima, A.C. 1953. Espécies de Eiphosoma Cresson (Hymenopt. Ichneumon. Ophion.). Arquivos do Museu Nacional Rio de Janeiro, 42: 175-189.

Lima, A.C. 1954. Nova Xiphosomella (Hymenoptera, Ichneumonidae, Ophioninae, (remastini). Revista Brasileira de Entomologia, 1: 169-171.

Lourenção, A.L.; Filho, E.B. \& Vasconcelos, D.F. 1982. Inimigos naturais de Mocis latipes (Ghenée, 1852). Bragantia, 41(9): 237-240.

Marconato, G.;Dias, M.M. \& Penteado-Dias, A.M. 2008. Larvas de Geometridae (Lepidoptera) e seus parasitóides, associadas a Erythroxylum microphyllum St.-Hilaire (Erythroxylaceae). Revista Brasileira de Entomologia, 52(2): 296-299. D0I

Massarolli, A.; Hoffmann, A.R.L.; Favetti, B.M. \& Butnariu, A.R. 2018. Ichneumonids (Hymenoptera) and tachinid flies (Diptera) associated to leptidopterans in soybean crops. Journal of Agricultural Science, 10(7): 167-173. D0I
Mazón, M. 2016. Taking shortcuts to measure species diversity parasitoid Hymenoptera subfamilies as surrogates of species richness. Biodiversity and conservation, 25(1): 67-76. D0I

Meierotto, S.; Sharkey, M.J.; Janzen, D.H.; Hallwachs, W.; Hebert, P.D.; Chapman, E.G. \& Smith, M.A. 2019. A revolutionary protocol to describe understudied hyperdiverse taxa and overcome the taxonomic impediment. Deutsche entomologische Zeitschrift, 66: 119-145. D01

Melo, I.F. \& Penteado-Dias, A.M. 2009. Estudo qualitativo das espécies de Eiphosoma Cresson, 1865 (Hymenoptera, Ichneumonidae, Cremastinae) em ecossistemas brasileiros. In: Congresso de Meio Ambiente da AUGM, $6^{0}$. Anais. São Carlos, Universidade Federal de São Carlos.

Melo, I.F.; Araújo, C.R. \& Penteado-Dias, A.M. 2015. New species of Exochus Gravenhorst and Trieces Townes (Hymenoptera, Ichneumonidae, Metopiinae) and first record of seven species from Brazil. Zootaxa, 4059(1): 40-50.

Melo, I.F.; Fernandes, D.R.R.; Lara, R.I.R.; Perioto, N.W. \& Dias A.M.P. 2009. Anomaloninae (Hymenoptera: Ichneumonidae) associados a cafeeiros (Coffea arabica L. cv. Obatã) em Cravinhos, SP. In: Congresso de Meio Ambiente da AUGM, $6^{\circ}$. Anais. São Carlos, Universidade Federal de São Carlos.

Mendonça, J.D.0;; Cervi, A.C. \& Guimarães, 0.A. 1998. 0 gênero Erythroxylum P. Browne (Erythroxylaceae) do estado do Paraná, Brasil. Brazilian Archives of Biology and Technology, 41(3): 349-358. D0I

Micheletti, S.M.F. \& Filho, E. 2000. Parasitoids of Cerconota anonella (Sepp., 1830) (Lep.: Oecophoridae) in soursop (Annona muricata L.). Scientia Agricola, 57(3): 565-566. D0I

Mittermeier, R.A.; Turner, W.R.; Larsen, F.W.; Brooks, T.M. \& Gascon, C. 2011. Global biodiversity conservation: the critical role of hotspots. In: Biodiversity hotspots. Berlin, Springer. pp. 3-22.

Moraes, R.R.; Loeck, A.E. \& Belarmino, L.C. 1991. Inimigos naturais de Rachiplusia nu (Guenée, 1852) e de Pseudoplusia includens (Walker, 1857) (Lepidoptera: Noctuidae) em soja no Rio Grande do Sul. Pesquisa Agropecuária Brasileira, 26(1): 57-64.

Morley, C. 1912. A revision of the Ichneumonidae based on the collection in the British Museum (Natural History) with descriptions of new genera and species. Part II. Tribes Rhyssides, Echthromorphides, Anomalides and Paniscides. London, British Museum. 140p.

Nava, D.E.; Parra, J.R.; Costa, V.A.; Guerra, T.M. \& Cônsoli, F.L. 2005. Population dynamics of Stenoma catenifer (Lepidoptera: Elachistidae) and related larval parasitoids in Minas Gerais, Brazil. Florida Entomologist, 88(4): 441-446. DOI

Neto, M.; da Costa, F.; Cruz, I.; Zanuncio, J.C.; Silva, C.H.O. \& Picanço, M.C. 2004. Parasitism by Campoletis flavicincta on Spodoptera frugiperda in corn. Pesquisa Agropecuária Brasileira, 39(11): 1077-1081. D0I

Onody, H.C. \& Penteado-Dias, A.M. 2016. A new species of Cryptophion (Hymenoptera: Ichneumonidae) from southeastern Brazil. Zoologia, Curitiba, 33(1): 1-5. DOI

Onody, H.C.; Frizo, M.I. \& Penteado-Dias, A.M. 2012. Abundância, riqueza e diversidade de espécies de Eiphosoma Cresson 1865 (Hymenoptera, Ichneumonidae, (remastinae) associada a hortas orgânicas. Idesia (Arica), 30(1): 115-120. DOI

Onody, H.C.; Sandonato, D.L. \& Penteado-Dias, A.M. 2013. First record and range extensions of Cryptophion Viereck, 1913 (Hymenoptera: Ichneumonidae) species in the Southeast region of Brazil. Check List, 9(3): 653-654. DOI

Ouedraogo, P.A.; Sou, S.; Sanon, A.; Monge, J.P.; Huignard, J.; Tran, B.E. \& Credland, P.F. 1996. Influence of temperature and humidity on populations of Callosobruchus maculatus (Coleoptera: Bruchidae) and its parasitoid Dinarmus basalis (Pteromalidae) in two climatic zones of Burkina Faso. Bulletin of Entomological Research, 86(6): 695-702. D0I 
Parker, H.L.; Silveria, A. \& Berry, P.A. 1950. Vegetable weevils and their natural enemies in Argentina and Uruguay. US Department of Agriculture, USA, Technical Bulletin, 1016: 1-27.

Patel, P.N. \& Habib, M.E.M. 1984. Levantamento e eficiência de insetos parasitos de Spodoptera frugiperda (Abbot \& Smith, 1797) (Lepidoptera, Noctuidae). Revista de Agricultura, 59: 229-237.

Quicke, D.L. 2012. We know too little about parasitoid wasp distributions to draw any conclusions about latitudinal trends in species richness, body size and biology. PLoS One, 7(2): 1-9. DOI

Quicke, D.L. 2015. The braconid and ichneumonid parasitoid wasps: Biology, systematics, evolution, and ecology. New Jersey, Wiley-Blackwell. 704p.

Quicke, D.L.J.; Fitton, M.G.; Notton, D.G.; Broad, G.R. \& Dolphin, K. 2000. Phylogeny of the subfamilies of Ichneumonidae (Hymenoptera): a simultaneous molecular and morphological analysis. In: Hymenoptera: evolution, biodiversity and biological control. Melbourne, CSIRO Publishing. p. 74-83.

Quicke, D.L.J.; Laurenne, N.M.L.; Fitton, M.G. \& Broad, G.R. 2009. A thousand and one wasps: a 285 rDNA and morphological phylogeny of the Ichneumonidae (Insecta: Hymenoptera) with an investigation into alignment parameter space and elision. Journal of Natural History, 43: 1305-1421. D0I

Sääksjärvi, I.E.; Haataja, S.; Neuvonen, S.; Gauld, I.D.; Jussila, R.; Salo, J. \& Burgos, A.M. 2004. High local species richness of parasitic wasps (Hymenoptera: Ichneumonidae; Pimplinae and Rhyssinae) from the lowland rainforests of Peruvian Amazonia. Ecological Entomology, 29(6): 735-743. DOI

Sandonato, D.L.; Onody, H.C. \& Penteado-Dias, A.M. 2010. Fauna de Campopleginae (Hymenoptera, Ichneumonidae) em hortas orgânicas em Araraquara e São Carlos, SP, Brasil. Biota Neotropica, 10(2): 117-121. D0I

Santos, A.D.; Onody, H.C. \& Brandão, C.R.F. 2019. Taxonomic contributions to the genus Charops Holmgren, 1859 (Hymenoptera: Ichneumonidae), with description of seven new species from Brazil. Zootaxa, 4619(1): 45-76.

Sauer, H.F.G. 1946. Constatação de himenópteros e dípteros entomófagos no estado de São Paulo. Boletim Fitossanitário, 3(1): 7-23.

Shimbori, E.M.; Onody, H.C.; Fernandes, D.R.R.; Silvestre, R.; Tavares, M.T. \& Penteado-Dias, A.M. 2017. Hymenoptera "Parasitica" in the state of Mato Grosso do Sul, Brazil. Iheringia. Série Zoologia, 107: 1-12. D0l

Silva, R.B.; Cruz. I, Figueiredo, M.D.L.C.; Bortoni, M.A.; Pereira, A.G.; Melo, I.F.; Camargo, L.F. \& Penteado-Dias, A.M. 2012. Record of new species of parasitoids on larvae of Spodoptera frugiperda (JE Smith) (Lepidoptera: Noctuidae) and Dichomeris famulata Meyrick (Lepidoptera: Gelechiidae) in maize (Zea mays L.) in Brazil. Revista Brasileira de Milho e Sorgo, 11(1): $115-119$.
Spöck, H. 2020. The biology of Raphidioptera: A review of present knowledge. Acta Zoologica Academiae Scientiarum Hungaricae, 48(2): 35-50.

Strassburg, B.B.; Brooks, T.; Feltran-Barbieri, R. Iribarrem, A. Crouzeilles, R. Loyola, R. \& Soares-Filho, B. 2017. Moment of truth for the Cerrado hotspot. Nature Ecology \& Evolution, 1(4): 1-3. D0I

Supeleto, F.A.; Santos, B.F.; Brady, S.G. \& Aguiar, A.P. 2020. Phylogenomic analyses reveal a rare new genus of wasp (Hymenoptera, Ichneumonidae, (ryptinae) from the Brazilian Atlantic Forest. Systematics and Biodiversity, 18(7): 646-661. D0I

Surgeoner, G.A. \& Wallner, W.E. 1975. Determination of larval instars of Heterocampa manteo and reduction of larval head capsule size by the parasitoid Diradops bethunei. Annals of the Entomological Society of America, 68(6): 1061-1062. DOI

Tanque, R.L.; Kumagai, A.F.; Frieiro-Costa, F.A. \& Souza, B. 2010. Ichneumonidae (Insecta: Hymenoptera) da Reserva do Boqueirão, IngaíMG. Revista Brasileira de Zoociências, 12(3): 241-247.

Townes, H. 1971. Ichneumonidae as biological control agents. Proceedings Tall Timbers conference on ecological animal control by habitat management, 3: $235-248$

Townes, H.K. \& Townes, M. 1966. A catalogue and reclassification of the Neotropic Ichneumonidae. Memoirs of the American Entomological Institute, 8: 1-367.

Veijalainen, A.; Broad, G.R. \& Sääksjärvi, I.E. 2014. Twenty-seven new species of Orthocentrus (Hymenoptera Ichneumonidae; Orthocentrinae) with a key to the Neotropical species of the genus. Zootaxa, 3768(3): 201-252. DOI

Wagener, B.; Reineke, A.; Löhr, B. \& Zebitz, C.P. 2006. Phylogenetic study of Diadegma species (Hymenoptera: Ichneumonidae) inferred from analysis of mitochondrial and nuclear DNA sequences. Biological Control, 37(2): 131-140.

Wahl, D.B. 1991. The status of Rhimphoctona, with special reference to the higher categories within Campopleginae and the relationships of the subfamily (Hymenoptera: Ichneumonidae). Transactions of the American Entomological Society, 117(3/4): 193-213.

Wahl, D.B. \& Bennett, A.M. 2020. First record of Nesomesochorinae (Hymenoptera: Ichneumonidae) from America north of Mexico with descriptions of two new species of Nonnus Cresson. Zootaxa, 4779(1): 38-50.

Yu, D.S.; van Achterberg, C. \& Horstmann, K. 2016. World Ichneumonoidea 2015. Taxonomy, biology, morphology and distribution. Taxapad interactive catalogue database on flashdrive. Ottawa, Nepean.

Zhaurova, K. \& Wharton, R. 2009. A revision of Physotarsus Townes (Hymenoptera: Ichneumonidae: Ctenopelmatinae), with description of 18 new species. Zootaxa, 2207: 1-52. 